\title{
The Development of Thematic Learning Model to Improve Students' Character in an Integrated Learning of Religion Education and Environment Towards Students in Adiwiyata School
}

\author{
Salman Assahary; Edi Barlian; Syafruddin Nurdin; Zulmuqim
}

STKIP PGRI Sumatera Barat, Indonesia

Email: salmanassahary@gmail.com

http://dx.doi.org/10.18415/ijmmu.v4i6.95

\begin{abstract}
This research is aimed at developing thematic learning model to improve students' character in an integrated learning of religion education and environment towards students in Adiwiyata school. Respondents in this research are grade $4^{\text {th }}$ students of Elementry School 02 and Elementry School 04 Tarandam area of Padang City of West Sumatera Province in Indonesia.The method used in this research is combining Borg \& Gall and Dick \& Carey 1 model. To see the effectiveness of the model, the researcher conducted three tests. They are 1-1 test, small test, and field trials test. There tests are used to figure out the students' character. The results of this research show that the thematic instructional model improved students' character with overall average score is 84,08 for the grade $4^{\text {th }}$ students in the two schools. In other words, it can be concluded that thematic learning model is effective for improving students' character in integrative of learning of religion education and enviroment for students who study at Adiwiyata school in Tarandam area of Padang City as above.
\end{abstract}

Keywords: Character; Thematic instructional model; Instructional model; Adiwiyata school; Environment; Religion education

\section{Introduction}

Adiwiyata program as environmentally friendly school, which became popoular in West Sumatra, as stated in the BAPEDALDA post (http://sumbarprov.go.id/2016/04/20). West Sumatera won 32 awards for national level for Adiwiyata schools, most of the winners are from Padang city. In 2016 BAPEDALDA passed 70 schools for Adiwiyata in the provincial level, where 25 schools are from Padang. Provincial level Adiwiyata schools will be proposed for Nasional level in 2017. Unfortunatly, the Adiwiyata schools environtment condition already decreased. It is seen that the participation awareness for environtmental care getting lower. It is look like that the students character only for participating on Adiwiyata championship, meanwhile the students environmental character is not ingrained yet. From the observation data, it is found that garbage strewn (trown everywhere/ not in its place), electricity energy waste, water pumps are leak, toilets are dirty. Additionally, the plants such as biological trees and beautiful flowers which are so green and fresh during the championship become dry, barren and dead. 
Religious education and the learning environment at Adiwiyata schools are being expected as the motor to increase the student's character to care about the environment. Unfortunatly in the reality this hope is not true yet. This fact occurs because of the system for maintain the environmental care character is not organized and integrated yet. Religious education teachers have difficulty on conducting a class that integrates the religious topics and the environment, due to the lack of understanding about Adiwiyata. Religious education teachers in managing learning activities in the class are not utilize environmentally friendly facilities and infrastructure those are available in the school of Adiwiyata (Salman Assahary, 2015: 8).

The learning model of Adiwiyata school which is not integrated yet on teaching and learning process is still conventional and the learning sources are from old books. The tasks of Adiwiyata school religion teachers, as instructional designer, manager of learning and learning, and outcomes evaluators, are to integrate religious education into environmental education. It is still patterned on the activities of teachers' oriented. In learning process, the teachers are more active on explaining the material, giving the task, asking the students to memorize more than develope the environtmental caring characters (Anisa Muslicha, 2015:6).

The implementation of unintegrated educational learning on environmental caring caused learning dificulty for students. The impact of ddifficulty on learning is decline in learning achievent (Afandi, Rifki. 2013:3). The low learning achievement on religious and environtmental education in Adiwiyata school students, SDN 02 and 04 Tarandam, implicatee to the decreasing of environmental caring characters.

The problem focus in this research is the development of thematic learning model to enhance the character of students in religious and environmental education integration in Adiwiyata school, SDN 02 and 04 Tarandam Padang. The research problems as follows: How the integration of learning and religious education model in Adiwiyata schools, SDN 02 and 04 Tarandam Padang City today? How to develop thematic learning model to enhance the character of students in religious education and environmental integration in Adiwiyata school SDN 02 and 04 Tarandam city of Padang? How the implementation and effectiveness of thematic learning model to enhance the character of students in religious education and environmental integration in Adiwiyata school, SDN 02 and 04 Tarandam city of Padang?

Thematic learning model is based on the theories of learning. Rusman describes the philosophical basis, the emergence of thematic learning is strongly influenced by the philosophy of the following three streams: (1) Progressivism, (2) constructivism and humanism (Rusman, 2012:255).

Meanwhile Dasim, Suparlan, and Meirawan, explain fundamentally that there are three main perspectives of the learning theory, behaviorism, cognitivism, and constructivism. First, behaviorism emphasizes learning success can be seen from the changes in behavior. Changes in the level of behavior here includes knowledge, skills and attitudes. The teacher's role here provides environmental, materials, media, visual aids, and designing the learning process well. Cognitivism Belalajar is the internal mental processes, including the process of understanding, the process of remembering, and the process of forming perceptions of things. Constructivism experience built directly by the students is the key to learning. Knowledge is the result of construction or human formation (Meirawan, 2009:45).

The development of thematic learning model is using Borg and Gall model steps for introduction research. Borg and Gall Model is a research development methodsthat is used to produce a particular product, and examine the effectiveness of the product. The advantages of this model is the initial research before product development. Next, to the development of products are using Dick and Carey development steps (Dick Walter, Louc Carey, 2005:83). Dick and Carey teps design can be seen as follow: 


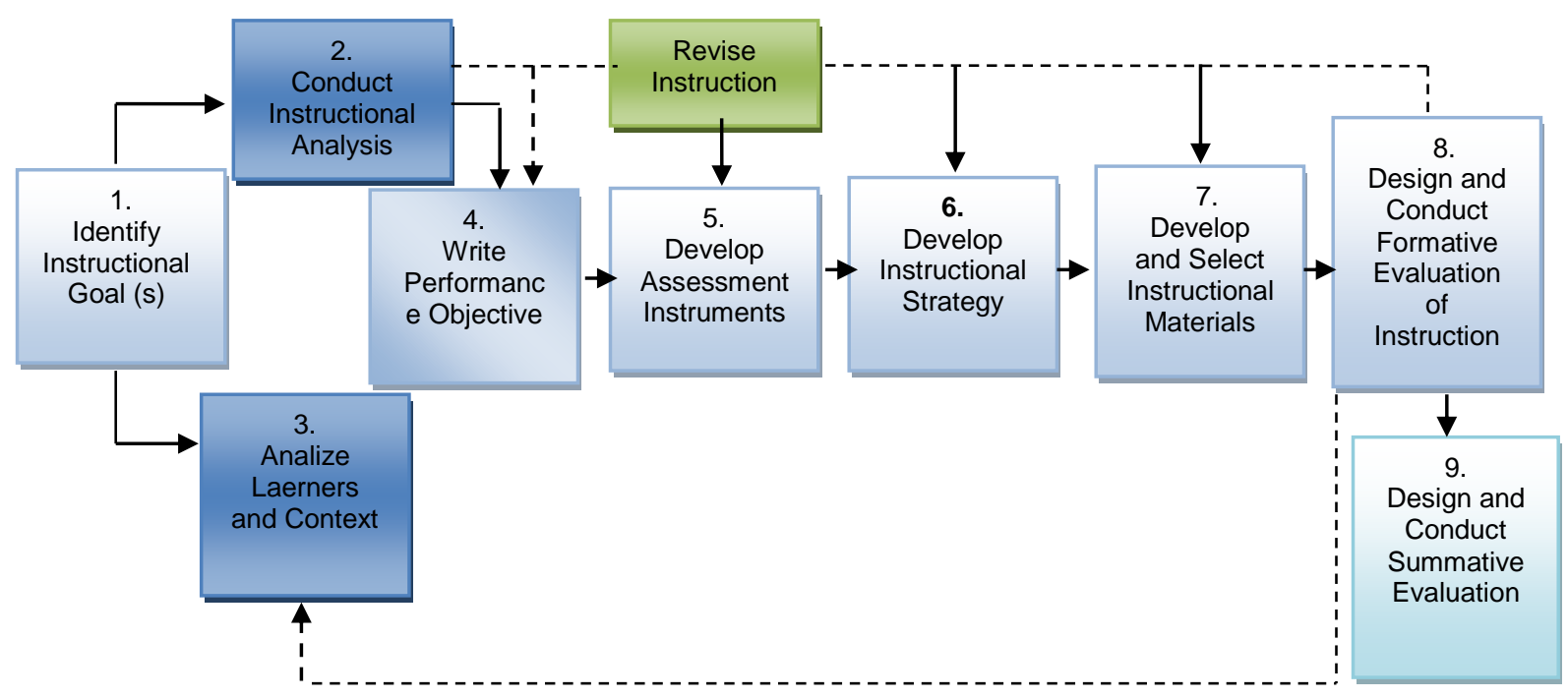

Fig. 1 Dick and Carey model. The systemic design of instruction

Dick and Carey Model consist of 10 steps. Each step has a very clear goals and objectives. The ten steps on the Dick and Carey model shows a clear and uninterrupted relationship between step one with the others. Dick and Carey excellence models lies in the analysis tasks that are organized in detail and specific learning objectives in a hierarchical manner. The trial repeatedly led the development becomes more tested. More detailed lesson plans, easy to follow, the revision of the learning analysis. The weakness of this model is that the trial is not spelled out clearly when to do and a new revision activities executed after having a formative test. Every step has been determined, though not all procedures are for implementation.Thematic learning is an integrated learning that uses the theme to associate some of the subjects that allows students, both individually or groups, active multiplication and find concepts and scientific principles in a holistic, meaningful, and authentic. Thematic learning model based on a variety of Fogarty learning theory (Fogarty, 2001:16).

Thematic learning model according to Kusnandar is an approach to learning that involves several fields of study to provide a meaningful experience to the students. Students will understand the concepts they learn through direct experience and relate it to other concepts, which they are already familiar. When compared with conventional approaches, integrated learning engages students physically and mentally active in teaching and learning activities in the classroom and in decision-making. John Dewey's opinion and his concept about "Learning By Doing" is in accordance with this thematic approach. Thematic learning approach can be seen as an effort to improve the quality of education at the primary level, especially in order to offset the curriculum stuffing symptoms that occur in the learning process in schools (Kusnandar, 2007:308).

Juridical of thematic learning associated with various policies or regulations of National Education Law, which supports the implementation of thematic learning in accordance with the characteristics model of thematic, they are: (1) students centered, (2) provide direct experience, (3) separation of subjects is not very clear, (4) presents the concept of various subjects, (5) presents the concept of the various subjects, (6) flexible, and (7) learning outcomes based on students' interests and needs. The steps of thematic models development is starting with basic competency mapping, network 
development themes, syllabus development and preparation of lesson plan. Basic competency mapping exercise was conducted to obtain an overall picture and full of all standards of the subjects. The next step choose a theme with the following principles: 1) noticed a nearby neighborhood with students, 2) from easy one to the difficult one, 3) simple towards the complex things, 4) from the concrete toward the abstract one, 5) the process of thinking on students occur, and 6 ) the scope of themes adapted to the age of the needs and the abilities of students.

Besides the importance of changing the learning model strategy, are also important to change the Adiwiyata school curriculum, which is still use SBC 2006 curriculum, and non of them use 2013 national curriculum. This change is necessary because public perception has been formed over the years, the curriculum SBC 2006 is only focused on cognitive aspects.

Environmental education curriculum changes which are inseparable part of the learning process in Adiwiyata schools is to seek integrated environmental learning into other subjects. Related to the efforts to increase the student's character, Religious subjects are integrated with environmental subjects as a solution to motivate students become environtment friendly and caring character education. It is the process to get information about the performance of learners (National Education Standards Agency, 2007: 3).

Describes the results of the assessment are used to evaluate the thoroughness of learners and the effectiveness of the learning process. Arifin, describes the assessment is a continuous process or activity to gather information about the process and learning outcomes of students in order to make decisions based on specific criteria and considerations. In accordance with this definition, each assessment is a deliberate process designed to obtain information (data). Based on these data and then try to make a decision. Assessment of education is an achiement of learners in achieving a specific outcome that is determined. At the level of subject competence that must be achieved by the students can be classified into several levels, in the form of standards of competence (SK) subjects which furthermore elaborated in basic competence (KD), while for the education unit level of competence to be achieved by the learners is the competency standards (SKL). Student learning outcomes can be influenced by the ability of the student's character. Therefore, in the learning naturally the characters need to be considered and developed in learning. Character education in the Law on National Education System is one of the missions that have been developed in an educational setting (Arifin, 2009:4).

According to Lickona, character has three interrelated parts of moral knowledge, moral feeling and moral behavior. Good character consists of knowing a good thing, wanting a good thing-habit in the way of thinking, habits and customs in the heart of the action. These three things are needed to direct a moral life and forming the moral maturity (Lickona, 2012:82).

According Megawangi, character is a term taken from the Greek meaning to mark, that is marking a person's actions or behavior. Someone can say the character (a person character) if its behavior in accordance with moral rules (Megawangi, 2007:3). Budimansyah explains that the character is relatively stable personal qualities of the individual self which is the basis for behavior in performance standards and norms of high value (Budimansyah, 2012: 3).

Thus it can be understood that the character is nature, quality, personality, moral, attitude or behavior that is inherent in every individual as well as the difference between a people with another person. So a person's character will be visible from one's spontaneous response when faced with a problem.

Education during elementary school is a period of initial formation for the development of a child's life, Prayitno, states that the purpose of education in primary schools support the achievement of

The Development of Thematic Learning Model to Improve Students' Character in an Integrated Learning of Religion Education and Environment

Towards Students in Adiwiyata School 
national education for the intellectual life of the nation and developed a complete Indonesian man, the man who: (1) faithful and devoted to God Almighty (2) noble character, (3) have the knowledge and skills, (4) physical and spiritual health, (5) steady and independent personality, (6) have a sense of civic responsibility (Prayitno, 1997:59).

The process of learning to be done well, then the learning materials in primary schools should be adapted to situations in real life, students need to be used to solve problems, find something useful for him, wrestle with ideas. In the learning process, students construct their own knowledge through active involvement in the learning process (Sardiman, 2006: 223).

According Abdurahman an-Nahlawi, in connection with the teaching of religion subject, states religion is a subject of individual and social arrangements that can cause a person subject to adhere to the religion and apply it perfectly in the lives of individuals and society (Abdurahman an-Nahlawi, 1989: 41). According Matta, religion subject is an attempt to study the process of changing the behavior of individuals guided by Islamic values in the life of their community and the environment through the educational process (Matta, 2006: 8).

According Hamid 'Abd, explains that study of religion is a process that leads people to the good life and the uplifting of humanity (Hamid 'Abd al-Qadir, 2007:5). According Lubis, stating that the Religion of learning form the personality of students in the learning process by using the religious education general principle of the learning process (Lubis, 2006: 16).

Based on the opinions of these experts can be understood that the process of religious education is a primary activity while environmental education can be called secondary activities that can be integrated into primary Adiwiyata school activities. Essenceially, learning achievement is determined by the professional and personal skills of teachers. It describes teachers as the spearhead of the field in curriculum development. Teachers should be creative in testing the curriculum in its class. Oemar Hamalik (2013: 231). Teachers must develop a curriculum, such as the integration of the environment into the religious teaching to improve the environmentally friendly caring character in Adiwiyata school.

\section{Method}

The method that is used in this research is the Research and Development with qualitative and quantitative approaches. The development of thematic learning model to enhance students' character is accomplished by Borg and Gall's model of preliminary research and Dick and Carey for development. Semiawan, explains to evaluate the various instruments necessary to assess giftedness should also set out the approach that the quantitative and qualitative methods. A qualitative approach was used so that researchers get information about the implementation of learning religious education and the learning environment in Adiwiyata schools. The quantitative method is done by using an evaluation instrument in the form of checklists (Semiawan, 2009: 14).

The observations made by good planning, it called as systematic observation. Evaluation instruments are form list to assess the skills of learners in a systematic observation. The instruments that are used in this study were questionnaires, interviews, and documentation. The validation of products are designed by the experts, media specialists and subject matter experts. Product trials conducted is one to one, small group, and large group. The analysis technique used is quantitative and qualitative. Quantitative data is data from questionnaires processed with SPSS and Excel while the qualitative data with the narrative or the words through data reduction, data presentation, and conclusion (Djaali \&Pudji, 2008: 17). 


\section{Result and Discussion}

\section{Implementation of Religious Education and Environmental Education}

Implementation of religious education and the learning environment in Adiwiyata schools SDN 02 and SDN 04 Tarandam Padang is not in accordance with one's vision and mission in this school. It is to improve the eco-friendly character on the student concerned. Opinions of teachers on the implementation of religious education and learning environment as a whole is $79 \%$ or 16 states have been implementing the learning well, $21 \%$ or 4 people have not implemented well. The method used in membelajaran student teachers are lectures, discussions, question and answer, and demonstrations. Books sources used are conventional books that do not contain environmental education. Syllabus and lesson plansbare created and developed by teachers. The opinions of students about religious education teaching and learning environment $52 \%$ or 14 students stated 'Yes', teachers have implemented learning to explain the specific goals of learning teaching religious education and the environment. Teachers become the most dominant resources teacher-centered.

\section{Thematic Learning Development Model}

Thematic learning development model refers to the model of Dick and Carey as follows: a) identification phase; b) developing phase; and c) evaluate and revise phase as follows:

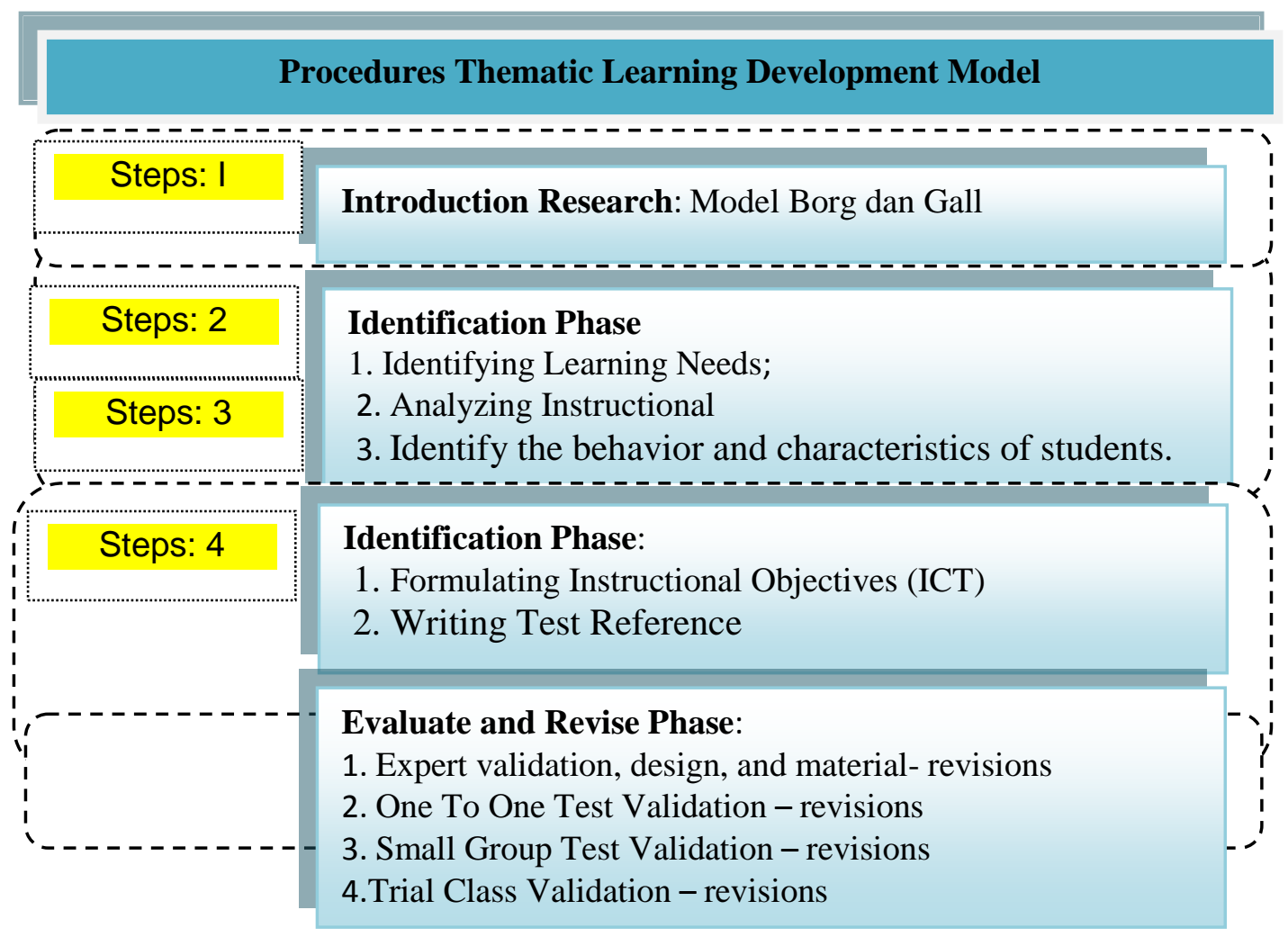

Fig. 2 Draft 2 procedures thematic learning development model 


\section{Introduction Research}

The quality of learning has not been fully achieved, but try to improve the quality of human resources by sending teachers to do the training or workshops. The results of the questionnaire of the students got 16 students stated the teacher made the preparation, implementation and evaluation of learning. 13 students stated the teacher is not preparing, implementing, and assessing learning outcomes.

\section{Identification Phase}

Identification phase elaborated in the results of the analysis of needs, which are: 1) identifying learning needs, 2) analyzing instructional, and 3) identify the behavior and characteristics of students.

\section{Developing Phase}

The development phase steps are as follows:

\section{(a) Formulating Instructional Objectives (ICT)}

This stage is to formulate an indicator or specific instructional objectives (ICT) from KD which is a common instructional goals (TIU). TIU and TIK formulated using the ABCD format (Audience, Behavior, Conditions and Degree).

\section{(b) Writing Test Reference}

Character assessment in the subjects of religious education and the environment frinedly and caring was developed based on reference assessment SBC, PP No. 19 Year 2007 on the National Standard theory of religious education and the environment and characters by Lickona, character has three interrelated parts that moral knowledge, moral feeling and moral behavior (Lickona, 2012: 82). These three things are needed to direct a moral life and forming the moral maturity is a specific field therefore the assessment and development of instruments can be performed by a religious and ethical environment with the assessment format to measure psychomotor ability with a score range 1-100.

\section{(c) Develop Instructional Strategies}

Some of the strategies those are developed in the syllabus and learning implementation plan are; contextual teaching and learning, discussion, question and answer, lectures, cooperative learning or group learning and demonstration. Directed learning strategies to develop students' knowledge based on experience

\section{(d) Developing Instructional Materials}

The developing teaching materials specifications which is adapted to religion subject and learning environment teaching materials of thematic models for teachers and students. Learning material has the following specifications: colored cover: blue, green and black. Typeface: Adobe Caslon, Font 58 for title. Theme: Comics Sons, Font 24, and the network behind the theme font 16. Posts: comic sons, font 14. 


\section{Evaluate and Revise Phase}

Evaluation phase is done by media expert validation, design, and material revisions, one to one test, small group trial, and a class experiment trial. In every phase of the evaluation be revised to improve the product.

(a) Expert validation experts design here provides validation of a design that includes aspects, syllabus, lesson plans and Instructional Materials.

(b) Expert design validation results of two experts, expert results design obtained first $81 \%$ and the second expert 83.5. Next, based on the results of discussions among the experts in connection with the syllabus design and lesson plans. Competency should be explained about the theme, the relationship between the components, general and specific instructional objectives, the material is too dense, competencies included in the components of cognitive, affective, and psychomotor. It is need to fit between matter and purpose, especially the connection between the themes and characters. Indicators of characters must be explained. The use of images, use of typeface must be able to distinguish between the head and the contents, as well as the size and color of the letters.

(c) Media Experts provide input related to the media that have been developed. Media expert validation result: first experts $74 \%$ and the second expert $86 \%$ is interpreted in good categories. Media developing interpreted good. Although in good categories, there are some things that need to be revised. This revision is based on input from media experts as follows: the material is too dense, some less appropriate pictures, to see the lay-out, use of the letters, type, size, and color combinations that must be read.

(d) Subject Matter Experts provide expert assessment for the first $75 \%$ and the second expert. 87\% Thus the material development considered good. The materials that are developing, includes the contents or basic materials such as; understanding the integration of religion and the environment, the basic element that contains the form and character examples of natural and environmental preservation are demonstrated quite helpful in developing the content of the material. Subject matter experts providing input to the learning device from the aspects of content with different dimensions.

(e) Evaluation of One to One is done among 8 students who have a fairly high learning outcomes. The material is easy to understand. Media aspects of the images are used in accordance with the content of the material. Selection of the typeface and the size of the letters are quite appropriate. The picture is quite clear. Photo design element there are some obvious but there are some less obvious picture as painted design elements, high, and low.

(f) Small Group Test is conducted by forming a special class consists of 16 students was selected randomly at SDN 02 and SDN 04. The selected students are the students who have the knowledge and ability of religious education and school environment. Students' opinion about the book developed in thematic learning model study was $81 \%$ in both categories. The boos outlook is $78 \%$, material $82 \%$, and the effectiveness of learning or character element is $84 \%$. Overall the learning materials or books that developed is quite well.

\section{(g) Trial Class}

After going through several phase of individual and small groups testing, the level of quality of the results of field trials conducted in the fourth grade students numbering 78 students scattered in SDN 02 and SDN 04 Tarandam Padang. 


\section{Final Model}

The final model is a model thematic learning device that had been evaluated. Final Model is a learning model character with the form; Syllabus, lesson plans and learning materials for teachers and students. Teaching materials (books teachers) and students' books as the final model is used by teachers and students in the process is as follows:

The final product as a result of the development of thematic model study, which is based on: (1) easy to use by teachers and students, (2) low costs, (3) easy to revision, and (4) easy to carry. Can be used by teachers and students devices with the following models:

\section{Feasibility Model}

The model that is developed has been discussed with 8 people, consisting of religion and science teachers as well as a professor of religion and environmental sciences from IAIN Imam Bojol Padang and Padang State University. The feedback that is given by teachers and professors of religion as an indicator in the integration of religion and the environment is directly used in the design development models of Dick and Carey. Overall framework of Draft 1 already explained the forms of activity model learning device utilization thematic berorietnasi on karakater development.

\section{Effectiveness Model}

\section{Students Character}

The results of the student's character after learning with thematic model study are as follows:

Table1 Students Character' Result

\begin{tabular}{|l|l|l|}
\hline \multicolumn{2}{|l|}{} & \multicolumn{2}{|l|}{ Students Character } \\
\hline & X1 & X2 \\
\hline \multicolumn{1}{|c|}{ Valid } & 21 & 22 \\
Mean & 1 & 0 \\
Median & 84.1429 & 86.9545 \\
Mode & 84.0000 & 85.0000 \\
Std. Deviation & $79.00^{\mathrm{a}}$ & 84.00 \\
Variance & 4.60745 & 3.96985 \\
Range & 21.229 & 15.760 \\
Minimum & 17.00 & 13.00 \\
Maximum & 72.00 & 79.00 \\
Sum & 89.00 & 92.00 \\
\hline
\end{tabular}

Multiple modes exist. The smallest value is shown

The characters test results X1 grader is 84.14 , and 86.95 for students of class $\mathrm{X} 2$ grader. The test results are taken from the student's character' test scores 1, test 2 and test 3. Character' test 1 average students score was 82.52. Second test average value of 82.04. Third test average 85.23. The average yield 
of student character value is summed and then, divided by 3. So, the value of the overall average grade student character X1 is 84.08 . Based on the results of the character analysis of student X1 class showed the average more than $85 \%$ (27 students) have completed their study or achieve mastery minimum standard value of 80 . While $15 \%$ (4 students) have not reached completeness characters in learn or do not meet the minimum completeness 80 value. Based on the results of the character analysis, after learning by using integrated thematic model on religion and the environment, it is showing effective models to improve the character of the students. This is based on the average value for class X2 showed an average of more than $90 \%$ (23 students) have completed their study or achieve mastery minimum standard value of 80 . While $10 \%$ (4 students) have not reached completeness of character in learning or does not meet the minimum completeness 80 value.

The test results of the student's character is taken from the value of the test 1 , test 2 and test 3 . Test 1 students' average score was 86.27. 2nd test average score is 85.54. 3rd test average value is 85.18. The average value of creativity X2 grader is 85.18. The impact of the implementation of the thematic model study to further students' character can be seen in the form of a pie chart picture below;

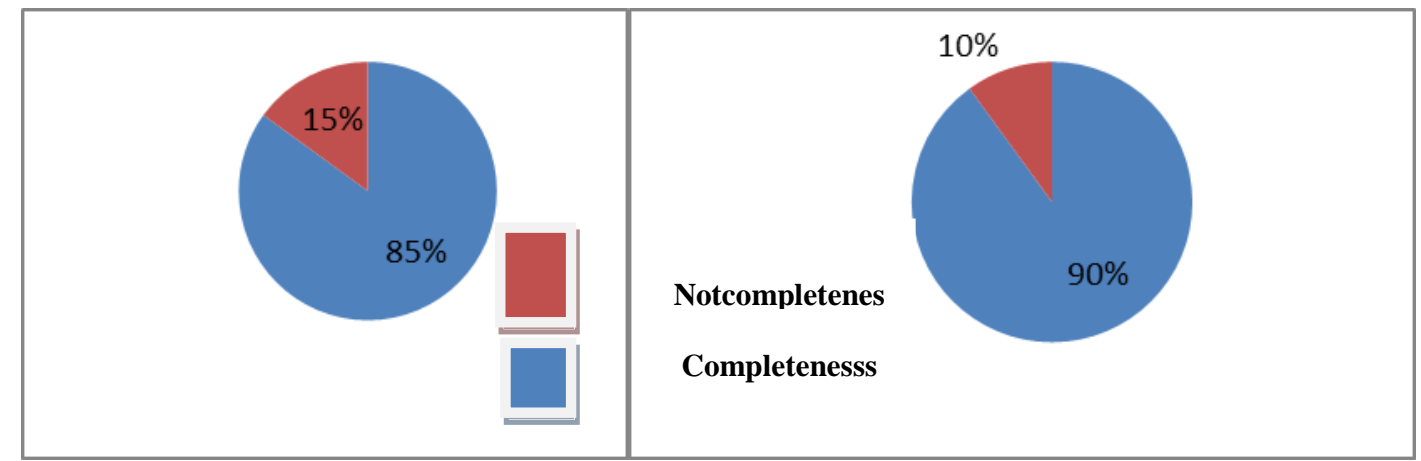

Fig 4.1 Characters completeness Student Class X1 and Figure 4.2. Characters completeness Student Class X2. (Values Character Results Grade)

\section{Impact on Students Results}

Results of the research on getting students' learning outcomes after learning with thematic model was 85.00 for dance class X1 grade and X2 grade 90.00, while for regular grade students are 79.00 and 77.80. Based on the results of student learning to learn with the learning model of thematic and nonthematic class students have seen the difference between the average value of 1.1 for students of class X1 grade and X2 grade 11.81. The results of this study showed that for X1 grade, the character impact is too thin or no impact occurs on student learning outcomes. For character X2 grade students gave a significant impact on student learning outcomes with the difference in the average value is 11.81 and it is concluded that the character may have an impact on student learning outcomes. 


\section{Discussion}

\section{Learning Integration of Religion and the Environment}

The results showed the implementation of the study of religion and the environment have been less relevant to develop improve student learning outcomes. Learning students' opinions about religion and the environment is still low. Implementation of the learning model with a model of lectures, demonstrations less facilitate interest and students' character. In addition, the references that is used by the teacher in the religious and less environmental legislation relevant to the education system.

\section{Thematic Learning Model Development}

The development of a thematic model study consisted of a conceptual model is the embodiment of the conceptualization of theories, principles, and the facts underlying the formation of thematic model learning. Procedural model is the embodiment stages Dick and Carey model design with the stage; identifying, developing, and evaluating revisions. Validation results of product design experts $81.6 \%$ in both categories, good $78 \%$ of media and subject matter experts good $78.1 \%$. For the evaluation of one to one that is quite interesting to see, easy to read and understand the material. Small group test showed $80 \%$ good results. The iimplementation of thematic model learning impact on student learning outcomes. The average value of student learning outcomes $\mathrm{X} 1$ grade is $79.2 \%$ or has reached the minimum value of the thoroughness of 78. Similarly, where the students of X2 grade average value of the student's character is 83, also has achieved minimum mastery value 77.

It can be concluded that thematic learning model is effectively to improve student learning outcomes. For religion and the environment lesson, the iimplementation of this thematic model study carried a positive impact on student learning outcomes. After studying the model of thematic students become more confident, characterless, dared to develop ideas, express opinions, easier to interpret experience, to develop knowledge of religion and the environment based on the knowledge he had. Students are also more focused in developing the theme of religion and the environment.

\section{Conclusion}

Based on the formula of interest and exposure to the results obtained in the research development of thematic model study for impact on improving learning outcomes religion and environment fourth graders in Adiwiyata school SDN 02 and SDN 04 Padang Tarandam it can be concluded as follows:

First, based on the results of preliminary studies on the implementation of the study of religion and the environment lesson that has lasted this long is a model of lectures, discussions, demonstrations and use old text books and conventional.

Second, the development of religious and environments learning tools have been done with the Dick and Carey model development steps. The measures undertaken in the developing stage is the formulation of specific instructional objectives (ICT), compiled reference test, develop instructional strategies, and develop teaching materials for teachers and students. The steps performed in the stage of evaluating and revising the formative stages, that is the expert evaluation of materials, design experts and media experts, evaluation of one to one (1-1), a small group evaluation and field trials (experiments in grade IV) The Adiwiyata school SDN 02 and SDN 04 Tarandam. Third, the development of thematic model study have an impact on improving student learning outcomes. It can be seen from the results of measurement of learning outcomes Based on the average value of the class for fourth graders showed an

The Development of Thematic Learning Model to Improve Students' Character in an Integrated Learning of Religion Education and Environment

Towards Students in Adiwiyata School 
average of 79.9 or more than $89 \%$ (19 students) have completed their study or achieve mastery minimum standard value is 78 . While 15\% (3 students) have not reached mastery for X2 grade students showed an average 85.18 this value indicates more than $90 \%$ ( 23 students) have completed their study or achieve mastery minimum standard value is 78 . The $10 \%$ (4 students) have not achieve mastery of character in learning yet or do not meet the minimum completeness 80 value.

Fourth, the implementation of thematic learning model on religion and integration learning environment after being effectively implemented, is visible from improving student learning outcomes and student opinion on thematic learning model in study of religion and environmental integration. Implementation stage is the stage where the model has a model ready for use. Implementation phase model consists of several steps, they are; a) implement the plan implementation, b) undertake implementation activities, and c) the follow up of the implementation. In connection with the results obtained from the development of learning tools in this thematic models researchers can recommend the follow:

1. Teachers can be used thematic model as part of the implementation of the learning process of integration of religion and the environment.

2. The implementation of learning geared to help students develop materials with direct experience and relate it to other concepts that have been understood.

3. Teachers and students need to understand well about thematic learning model, because this model of thematic learning is an instructional model that can be said to be comprehensive, because in addition to providing the insight to students, also in terms of affective stimulates the students themselves.

4. Teachers also can develop learning or modify the learning to the development of media. So the teacher was not solely focused on the body's use of media in learning.

5. Teachers prepare competency ability to combine not only the learning material, but also must be able to share other subjects to become a unified whole.

\section{References:}

Books :

Abdul- Muhmin, A.G. (2016). Explaining Consumer's Willingness to be Environmentally Friendly. International Journal of Consumer Studies 2016.

Ajzen, I. (2015). The Theory of Planned Behaviour. Journal of Organizational Behaviour and Human Decision Processes.

An-Nahlawi, A. (1989). Usluhut Tarbiyatil Islamiyah wa Asalibuha. Terjemahan Ali, H.N. Bandung: Diponegoro.

Arifin, Zainal. (2011). Konsep dan Model Pengembangan Kurikulum. Bandung: Rosdakarya.

Badan Standar Nasional Pendidikan, Panduan Penilaian Kelompok Mata Pelajaran Ilmu Pengetahuan dan Teknologi. Jakarta:BSNP, 2007. 
Bapedalda propinsi Sumatera Barat (http;//sumbarprov.go.id/2016/04/20).

Bolck, Jack. (2002). Personality as an Affect-Processing System. London: Lawrence.

Borg, Walter R., Meredith D. Gall. (1983). Educational Research An Introduction, Longman Inc. New York;

Clark, Barbara. Integrative Education. http//www.education.jhu (diakses 3 Maret 2017).

Craft, Anna, Bob Jefrey, dan Mike Leibling. Creativity in Education. London: Bidles Ltd, 2007.

Dasim Budimansyah,. Suparlan, dan Danny Meirawan. Pembelajaran Aktif, Kreatif, Efektif, dan Menyenangkan. Bandung: Genesindo, 2009.

Dick, Walter, Lou Carey, dan James O Carey. (2009). The Systematic Design of Instructional. Amerika: Pearson.

Direktorat Jendral Pendidikan dan Menengah Kementrian Pendidikan dan Kebudayaan. Kebijakan Program Pendidikan dan Tenaga Kependidikan. http://www. dikdas. kemendiknas.go.id (diakses 19 February 2017).

Djaali dan Pudji Muljono. Pengukuran dalam Bidang Pendidikan. Jakarta: Grasindo, 2008. E.Kristi Poerwandari, Pendekatan Kualitatif Untuk Penelitian Perilaku Manusia, Jakarta : LPSP3 UI.

Fogarty, Robin. (2001). Integrate the Curricula. Amerika: IRI/Sky Light Training.

Gagne, R. M. (1985). The Conditions Of Learning And Theory Of Instruction. New York: CBS College Publishing.

Gall, M.D. Gall dan Borg. (1989). W.R. \&, Educational Research: An Introduction, Fifth Edition. New York: Longman.

Gustafson, Kent L. dan Robert Maribe Branch. (2002). Survey of Instructional Development Models. USA: Eric.

Hamid 'Abd al-Qâdir. (2007). Kuliyyah Ushûl al-Dîn Mudzâkarât fi al-Tarbiyyah. Cairo:1431 H AlJâmi’ah al-Azhar.

Kusnandar. (2007). Guru Profesional Implementasi Kurikulum Tingkat Satuan Pandidikan (KTP) dan Persiapan menghadapi Sertifikasi Guru. Jakarta: Rineka Cipta.

Lickona, T. (2012). Mendidik Untuk Membentuk Karakter: Bagaimana Sekolah Dapat Memberikan Pendidikan tentang Sikap Hormat dan Tanggung Jawab. Jakarta: Bumi Aksara.

Lubis, S.H. (2006). Rahasia Kesuksesan Halaqoh (Usroh). Tanggerang: FBA Press.

Matta, M. A. (2006). Membentuk Karakter Cara Islam. Jakarta: Al'tishom Cahaya Umat.

Megawangi,R. (2007). Pendidikan Karakter: Solusi yang Tepat untuk Membangun Bangsa. Depok: Indonesia Heritage Foundation. 
Oemar Hamalik, (2013). Dasar-dasar Pengembangan Kurikulum: Bandung, Remaja Rosadakarya.

Prayitno. Dkk. (2006). Studi Pengembangan Aplikasi High-Touch dan High-Tech Dalam Proses Pembelajaran di Sekolah. Penelitian Hibah Pascasarjana Tahun Pertama. Padang. Universitas Negeri Padang.

Sandjaya, Wina. (2008). Perencanaan dan desain Sistem Pembelajaran. Jakarta: PT. Kencana Prenanda Media Group;

Sardiman. (2006). Interaksi\& Motivasi Belajar Mengajar. Jakarta: Raja Grafindo.

Semiawan, Conny.(2002). Belajar dan Pembelajaran Dalam Taraf Pendidikan Usia Dini. Jakarta: Prenhallindo.

Slavin, R. E. (2009). Cooperative Learning : Teori, Riset dan Praktik. Bandung: Nusa Media.

Sugiyono. (2008). Metode Penelitian Pendidikan (Pendekatan Kuantitatif, Kualitatif, dan R\&D). Bandung: Alfabeta.

Suharsimi Arikunto. (2012). Dasar-dasar Evaluasi Pendidik Pendidikan, Jakarta: Bumi Aksara.

Suryatri, Darmiatun, (2013). Menyusun Model Bahan Ajar untuk Persiapan Guru dalam Mengajar. Yogyakarta: Gava Media.

Wahab,A,A \& Sapriya. (2011). Teori dan Landasan pendidikan Kewarganegaraan.Bandung: Alfabeta $\mathrm{CV}$.

Zainal Arifin. (2009). Evaluasi Pembelajaran, Prinsip Teknik dan Prosedur. Bandung: Rosdakarya.

\section{Journals:}

Anisa Muslicha. (2015). "Metode Pengajaran dalam Pendidikan Lingkungan Hidup Pada Siswa Sekolah Dasar" (Studi Pada Sekolah Adiwiyata di DKI Jakarta) Jurnal Pendidikan, 16(2), September 2015, 110-126.

Salman Assahary (2013), Upaya Penyadaran Masyarakat dalam Pengelolaan Sampah di Kelurahan Kurao Pagang Kota Padang Berdasarkan Amanat UUD No 18 Tahun 2008 Tentang Pengelolaan Sampah Jurnal Erudisi, Universitas Eka Sakti Padang, ISSN 2087- 8370.

Salman Assahary. (2012), Manajemen Pengeloloaan Sampah Berbasis Budaya Lokal di Kota Padang, Seminar Nasional Tantangan Pembangunan Berkelanjutan dan Perubahan Iklim di Indonesia, Kota Medan Vol. 5/No. 2/Juni.

Salman Assahary. (2011), Peningkatan Peranan Dakwah dalam Menyelesaian Konflik Lingkungan Tahun 2011 pp. 61- 69, Jurnal Ipteks Terapan Kopertis Wilayah X. di Sumatera Barat, Vol. 5/No. 2/Juni.

Salman, Assahary. (2010). Penyelesaian Konflik Lingkungan Berbasis Dakwah di Minangkabau,Konferensi Nasional Penanggulangan Bencana danLingkungan”,ISBN 1001005849675, 4- 5 di Padang. 
Ghanis, Nunuk, Suharno, (2013), Pengembangan Model Internalisasi Nilai Karakter Dalam IPS Di SMP Se Solo Raya, Jurnal Pendidikan dan Pembelajaran, vol.1.No.3, hal 387-389 ISSN: 2354-6441.

Nunuk Suryani, (2013), Pengembangan Model Internalisasi Nilai Karakter dalam Pembelajaran, Jurnal Paramita, Vol. 23. No-2- Juli (ISSN 0854-0039).

N.M. Rumidani, A.A.I.N Marhaeni, dan I. N. Tika. 2014. "Implementasi Pembelajaran Tematik Berbasis Lingkungan Untuk Meningkatkan Motivasi dan Hasil Belajar Calistung Siswa Sekolah Dasar". Universitas Pendidikan Ganesha Program Studi Pendidikan Dasar. Vol. 4, p. 1-7.

Yusof, N.M, Anna C.A. Norlida A, (2014) "Multicultural Education Practices in Malaysian Preschool with Multiethnic or Monoethnic Environment", International Journal of Multicultural and Multireligious Understanding, 1,1,12-23. doi: 10.18415/ijmmu.

\section{Proceeding :}

Salman,Assahary. (2015). "Model Kesadaran Perilaku Warga Sekolah Adiwiyata dalam Pengelolaan Sarana Ramah Lingkung di Kota Padang" Proceeding Hilirisasi dan Komersialisasi Hasil-hasil Penelitian Universitas PGRI Semarang, (Vol. 01/No. 01/12/ 2015 pp.33.44. ISBN: 978-602-0960-296).

Salman Assahary. (2009). Perubahan Sosial Dan Etika Lingkungan Masyarakat dilokasi Pembangunan Kampus II UBH, Proceeding Konferensi Nasional Penanggulangan Bencana dan Lingkungan, pp 246- 252, ISSN: 2087- 6343, di Sumatera Barat.

Salman Assahary. (2014). Model Penyadaran Masyarakat dalam Pengelolaan Sampah Berbasis Kearifan Budaya Lokal (Adat Basandi Syarak, Syarak Basandi Kitabullah) di, Kota Padang, Univ.Andalas, Prosiding SNSTL I 2014 ISSN 2356- 4938.

Yadi Ruyadi. (2010). "Model Pendidikan Karakter Berbasis Kearifan Budaya Lokal (Penelitian Terhadap Masyarakat Adat Kampung Benda Kerep Cirebon Provinsi Jawa Barat untuk Pengembangan Pendidikan Karakter di Sekolah) Proceedings of The 4th International Conference on Teacher Education; Join Conference UPI \& UPSI Bandung, Indonesia, 8-10 November 2010.

\section{Copyrights}

Copyright for this article is retained by the author(s), with first publication rights granted to the journal.

This is an open-access article distributed under the terms and conditions of the Creative Commons Attribution license (http://creativecommons.org/licenses/by/4.0/). 